\title{
Lack of micronucleus induction activity of ethyl tertiary-butyl ether in the bone marrow of F344 rats by sub-chronic drinking-water treatment, inhalation exposure, or acute intraperitoneal injection
}

\author{
Tadashi Noguchi'1, Tomoyuki Kamigaito', Taku Katagiri'1, Hitomi Kondou', \\ Kazunori Yamazaki ${ }^{1}$, Shigetoshi Aiso', Tomoshi Nishizawa1', Kasuke Nagano² \\ and Shoji Fukushima ${ }^{1}$ \\ 'Japan Bioassay Research Center, Japan Industrial Safety and Health Association, \\ 2445 Hirasawa, Hadano, Kanagawa 257-0015, Japan \\ ${ }^{2}$ Nagano toxicologic-Pathology Consulting, Ochiai, Hadano, Kanagawa 257-0025, Japan
}

(Received June 19, 2013; Accepted September 8, 2013)

\begin{abstract}
Ethyl tertiary-butyl ether (ETBE) is an oxygenated gasoline additive synthesized from ethanol and isobutene that is used to reduce $\mathrm{CO} 2$ emissions. To support the Kyoto Protocol, the production of ETBE has undergone a marked increase. Previous reports have indicated that exposure to ETBE or methyl tertiary-butyl ether resulted in liver and kidney tumors in rats and/or mice. These reports raise concern about the effects of human exposure being brought about by the increased use of ETBE. The present study was conducted to evaluate the genotoxicity of ETBE using micronucleus induction of polychromatic erythrocytes in the bone marrow of male and female rats treated with ETBE in the drinking-water at concentrations of $0,1,600,4,000$ or $10,000 \mathrm{ppm}$ or exposed to ETBE vapor at $0,500,1,500$ or 5,000 ppm for 13 weeks. There were no significant increases in micronucleus induction in either the drinking wateradministered or inhalation-administered groups at any concentration of ETBE; although, in both groups red blood cells and hemoglobin concentration were slightly reduced in the peripheral blood in rats administered the highest concentration of ETBE. In addition, two consecutive daily intraperitoneal injections of ETBE at doses of $0,250,500$ or $1,000 \mathrm{mg} / \mathrm{kg}$ did not increase the frequency of micronucleated bone marrow cells in either sex; all rats receiving intraperitoneal injections of ETBE at a dose of 2,000 $\mathrm{mg} / \mathrm{kg} \mathrm{died}$ after treatment day 1 . These data suggest that ETBE is not genotoxic in vivo.
\end{abstract}

Key words: Ethyl tertiary-butyl ether, ETBE, Inhalation, Drinking-water, Micronucleus, Rat, Bone marrow

\section{INTRODUCTION}

Ethyl tertiary-butyl ether (ETBE) is chemically synthesized from bioethanol and isobutene and when blended with gasoline ETBE acts as an oxygenate: Oxygenates are added to unleaded gasoline to enhance the octane rating and reduce exhaust emissions. To support the requirement of the Kyoto Protocol for reducing $\mathrm{CO} 2$ emissions, the Petroleum Association of Japan decided to use ETBE as a gasoline additive. While the use of oxygenated motor fuels can have beneficial environmental consequences, humans can be exposed to oxygenates both orally and by inhalation (Ahmed, 2001; McGregor, 2006, 2007), and the increased use of ETBE as a gasoline additive will increase human exposure. Exposure of the public to ETBE can be by inhalation of vapor by released from gas-stations and by drinking water contaminated with ETBE by leakage of gasoline from underground storage tanks (McGregor, 2007).

The toxicity data for ETBE is limited and inconsistent; therefore, the health hazard presented by ETBE is uncertain. Medinsky et al. (1999) reported that inhalation exposure to ETBE for 13 weeks caused centrilobular hepatocyte hypertrophy in male and female mice, testicular

Correspondence: Tadashi Noguchi (E-mail: tadashi-noguchi@jisha.or.jp) 
toxicity in rats but not in mice, male rat specific $\alpha_{2 u}$-globin nephropathy, and an increased incidence of bone marrow congestion in female rats. Bird et al. (1997) exposed F344 rats and CD-1 mice to methyl tertiary-butyl ether (MTBE); a widely used oxygenate developed during the Second World War that is chemically similar to ETBE) for 24 months and 18 months via inhalation, respectively, and found an increased incidence of renal tubular cell tumors in male rats, increases in the incidence and severity of chronic progressive nephropathy in male and female rats, and an increased incidence of hepatocellular adenomas in female mice. However, in a review of the health hazards of MTBE, McGregor (2006) notes that the results of the carcinogenicity studies of MTBE are generally not consistent and replication of results was observed in only three cases, none of which had human relevance. In a more recent study, Saito et al. (2013) reported that inhalation exposure to ETBE for 104 weeks caused a significant increase in hepatocellular adenomas in male, but not in female, rats. When administered by gavage, ETBE is reported to have carcinogenesis activity. Maltoni et al. (1999) administered ETBE to male and female SD rats by oral gavage for 104 weeks and found a significant dose-related increase of mouth and forestomach tumors, uterus malignant tumors and hemolymphoreticular neoplasms, and Hagiwara et al. (2011) using a multi-organ carcinogenesis bioassay found that ETBE promoted tumorigenesis of the thyroid, forestomach, colon, liver, kidney and urinary bladder in male rats by oral gavage for 28 weeks. In contrast, Suzuki et al. (2012) administered ETBE to male and female rats in the drinking water for 104 weeks and found that ETBE did not have any carcinogenic effect. Thus, the results of the carcinogenicity studies of ETBE are mixed.

Studies investigating the genotoxicity of ETBE and MTBE in vitro have also been reported (Table 1). The results of several in vitro genotoxicity studies testing the mutagenic activity of ETBE and MTBE using bacterial mutation tests and chromosomal aberration tests in cultured mammalian cells were negative (Zeiger et al., 1992; Kado et al., 1998; Williams-Hill et al., 1999; McGregor et al., 2005; Zhou et al., 2000; Mackerer et al., 1996; McKee et al., 1997; McGregor et al., 2006, 2007). However, other studies report that MTBE induced mutations in Salmonella typhimurium TA102 and in the mouse lymphoma L5178Y cell $t k$ locus assay and induced DNA-strand breaks in human HL-60 leukemia cells (Williams-Hill et al., 1999; Mackerer et al., 1996; McGregor, 2006, 2007).

Although some in vivo genotoxic studies of ETBE have been reported, these are unpublished and unknown for details (Table 1). MTBE was reported to be negative in bone marrow chromosomal aberration and micronucleus tests (McKee et al., 1997; Kado et al., 1998; McGregor, 2006, 2007), but DNA strand breakage in peripheral lymphocytes from SD rats dosed with $800 \mathrm{mg} / \mathrm{kg} /$ day of MTBE by gavage for 28 days were reported to be significantly increased (Lee et al., 1998; McGregor, 2006).

To investigate the in vivo genotoxicity of ETBE, we performed the bone marrow micronucleus assay after administration of ETBE to F344 rats of both sexes by three different routes: Rats were exposed to ETBE vapor for 13-weeks, ETBE in the drinking-water for 13-weeks, or ETBE by intraperitoneal injections for two consecutive days. Each 13-week study was carried out as a preliminary examination for a dosage setup of a carcinogenicity test (Suzuki et al., 2012; Saitou et al., 2013). All experiments were carried out in accordance with standard test guidelines and good laboratory practices (GLPs).

\section{MATERIALS AND METHODS}

This study was conducted from 2006 to 2007 in accordance with the Organization for Economic and Co-operation and Development (OECD) Guidelines for Testing of Chemicals TG408, TG413, TG474 (OECD, 1998, 1981 and 1997), and in accordance with the OECD principles of GLP (OECD, 1998). The animals were cared for in accordance with the Guide for the Care and Use of Laboratory Animals (NRC, 1996) and the present studies were approved by the ethics committee of the Japan Bioassay Research Center (JBRC).

\section{Chemicals}

The ETBE (CAS No. 637-92-3) used in the present study was manufactured by Tokyo Chemical Industry Co., Ltd. (Tokyo, Japan), with the following specifications (quoted from the SDS in Tokyo Chemical Industry Co., Ltd., 2012): appearance, colorless transparent liquid; boiling point, $70^{\circ} \mathrm{C}$; vapor pressure, $17 \mathrm{kPa}\left(25^{\circ} \mathrm{C}\right)$; solubility, slightly soluble in water $1.2 \mathrm{~g} / 100 \mathrm{~g}, 25^{\circ} \mathrm{C}$; purity, $>99 \%$ (measured by Toray Research Center Co., Ltd., Tokyo, Japan); storage condition, in the dark at room temperature. The stability of the ETBE was measured using a gas chromatograph (Hewlett Packard 5890A, Agelent Technologies Inc., Santa Clara, CA, USA) before the beginning and at the end of the test period; the data from the two time points were compared to assess the stability of the ETBE in the administration vehicle: There were no differences between the results at the beginning and the end of the test period. 
Micronucleus induction activity of ethyl tertiary-butyl ether

Table 1. Summary of studies of MTBE and ETBE genotoxicity

\begin{tabular}{|c|c|c|c|c|c|}
\hline & Endpoint & Test system & Dose & Result & Reference \\
\hline \multirow[t]{9}{*}{ MTBE } & \multirow[t]{4}{*}{$\begin{array}{l}\text { Mutation } \\
\text { in vitro }\end{array}$} & $\begin{array}{l}\text { Salmonella typhimurium } \\
\text { TA97, TA98, TA100, TA1535 }\end{array}$ & $7,400 \mu \mathrm{g} /$ plate & Negative & Kado et al. (1998) \\
\hline & & $\begin{array}{l}\text { Salmonella typhimurium } \\
\text { TA102 }\end{array}$ & $750 \mu \mathrm{g} /$ plate & Positive & Williams-Hill et al. (1999) \\
\hline & & $\begin{array}{l}\text { Salmonella typhimurium } \\
\text { TA98, TA100, TA1535, TA1537, TA102 }\end{array}$ & $5,000 \mu \mathrm{g} /$ plate & Negative & McGregor et al. (2005) \\
\hline & & $\begin{array}{l}\text { mouse lymphoma L5178Y cells } \\
t k \text { locus }\end{array}$ & $740 \mu \mathrm{g} / \mathrm{ml}$ & Positive & Mackerer et al. (1996) \\
\hline & $\begin{array}{l}\text { Micronucleus } \\
\text { formation } \\
\text { in vitro }\end{array}$ & mouse NIH/3T3 cells & $14,000 \mu \mathrm{g} / \mathrm{ml}$ & Negative & Zhou et al. (2000) \\
\hline & $\begin{array}{l}\text { DNA damage } \\
\text { in vivo }\end{array}$ & $\begin{array}{l}\text { SD rat } \\
\text { peripheral lymphocytes (comet assay) }\end{array}$ & $\begin{array}{l}800 \mathrm{mg} / \mathrm{kg} / \mathrm{day} \\
\text { (gavage injection for } 28 \\
\text { days) }\end{array}$ & Positive & Lee and Quitana (1998) \\
\hline & \multirow[t]{3}{*}{$\begin{array}{l}\text { Micronucleus } \\
\text { formation } \\
\text { in vivo }\end{array}$} & $\begin{array}{l}\text { male and female CD-1 mouse } \\
\text { bone marrow cells }\end{array}$ & $\begin{array}{l}8,000 \mathrm{ppm} \\
\text { (inhalation for } 6 \mathrm{hr} / \text { day } \\
\text { for } 2 \text { days) }\end{array}$ & Negative & McKee et al. (1997) \\
\hline & & $\begin{array}{l}\text { male and female Swiss-Webster mouse } \\
\text { bone marrow cells }\end{array}$ & $\begin{array}{l}1,750 \mathrm{mg} / \mathrm{kg} \\
\text { (single ip treatment) }\end{array}$ & Negative & Kado et al. (1998) \\
\hline & & $\begin{array}{l}\text { male and female F344 rat } \\
\text { bone marrow cells }\end{array}$ & $\begin{array}{l}8,000 \mathrm{ppm} \\
\text { (inhalation for } 6 \mathrm{hr} / \text { day } \\
\text { for 5days) }\end{array}$ & Negative & McKee et al. (1997) \\
\hline \multirow[t]{5}{*}{ ETBE } & \multirow[t]{2}{*}{$\begin{array}{l}\text { Mutation } \\
\text { in vitro }\end{array}$} & $\begin{array}{l}\text { Salmonella typhimurium } \\
\text { TA97, TA98, TA100, TA1535 }\end{array}$ & $10,000 \mu \mathrm{g} /$ plate & Negative & Zeiger et al. (1992) \\
\hline & & $\begin{array}{l}\text { Chinese hamster V79 cells } \\
\text { hprt locus }\end{array}$ & $5,000 \mu \mathrm{g} / \mathrm{ml}$ & Negative & $\begin{array}{l}\text { Bushy Run Research Center } \\
(1995)^{*}\end{array}$ \\
\hline & $\begin{array}{l}\text { Chromosomal } \\
\text { aberrations } \\
\text { in vitro }\end{array}$ & Chinese hamster ovary cells & $5,000 \mu \mathrm{g} / \mathrm{ml}$ & Negative & $\begin{array}{l}\text { Bushy Run Research Center } \\
(1995)^{*}\end{array}$ \\
\hline & \multirow[t]{2}{*}{$\begin{array}{l}\text { Micronucleus } \\
\text { formation } \\
\text { in vivo }\end{array}$} & $\begin{array}{l}\text { male and female OF- } 1 \text { mouse } \\
\text { bone marrow cells }\end{array}$ & $\begin{array}{l}5,000 \mathrm{mg} / \mathrm{kg} \\
\text { (single gavage } \\
\text { treatment) }\end{array}$ & Negative & Insitut Pasteur de Lille (1992)* \\
\hline & & $\begin{array}{l}\text { male and female CD-1 mouse } \\
\text { bone marrow cells }\end{array}$ & $\begin{array}{l}5,000 \mathrm{ppm} \\
\text { (inhalation for } 6 \mathrm{hr} / \mathrm{day} \\
\text { for 5days) }\end{array}$ & Negative & $\begin{array}{l}\text { Bushy Run Research Center } \\
(1995)^{*}\end{array}$ \\
\hline
\end{tabular}

*: Unpublished report, quoted from McGregor (2006).

\section{Animals and husbandry}

For the 13-week studies of oral administration and inhalation exposure to ETBE, F344/DuCrlCrlj rats of both sexes were obtained at the age of 4 weeks for the from Charles River Japan, Inc. (Kanagawa, Japan), and for the intraperitoneal injection study, F344/DuCrlCrlj rats of both sexes were obtained at the age of 6 weeks from Charles River Japan, Inc. All rats were individually quarantined and acclimated for 1 week prior to the beginning of the ETBE administration period. Animals exposed to ETBE by inhalation were individually housed in cages placed in 1060 liter stainless steel inhalation exposure chambers. The environment in the exposure cham- bers was maintained at a temperature of $20-24^{\circ} \mathrm{C}$ and a relative humidity of $30-70 \%$ with 13 air changes per hour. The exposure chambers were installed in a controlled system animal room. The animals administered ETBE in the drinking water or by intraperitoneal injection were housed individually in stainless steel wire-mesh cages in a barrier controlled animal room (temperature $23 \pm 2{ }^{\circ} \mathrm{C}$, relative humidity $55 \pm 15 \%, 15-17$ ventilation frequencies per hour). Fluorescent lighting was controlled automatically to give a 12-hr light/dark cycle. All rats were given $30 \mathrm{kGy}-\gamma$ ray irradiation sterilized commercial pellet diet (CRF-1, Oriental Yeast Co., Ltd., Tokyo, Japan) and sterilized water ad libitum. 


\section{Experimental design 13-week drinking-water study}

After quarantine and acclimation, the rats were divided by stratified randomization into 6 body weight-matched groups of each sex, each comprising 10 rats. Rats were given drinking water containing 0 (control), 250, 640, $1,600,4,000$ or $10,000 \mathrm{ppm}$ (wt/wt) ETBE starting at 6 weeks of age for 13 weeks. The highest concentration of ETBE used was determined based on the maximum tolerated dose (MTD) obtained from a preliminary 28-day oral gavage toxicity study and the solubility of ETBE in water, which is $12,000 \mathrm{ppm}$. Drinking water containing ETBE was prepared by dissolving ETBE in deionized water in a stainless-steel container. After mixing for one hour in order to completely dissolve the ETBE in the water, the container was connected to the automatic watering system and pressurized to $0.05 \mathrm{MPa}$ in order to prevent vaporization of ETBE from the drinking water (Kano et al., 2002). ETBE-containing water or vehicle water was supplied to rats in individual groups and replaced with newly prepared drinking water once a week. The ETBE concentration in the drinking water at each dose level was analyzed by a headspace gas chromatograph (Hewlett Packard 5890A, Agelent Technologies Inc.) and found to be within $91 \%$ to $110 \%$ of the target concentrations.

\section{3-week inhalation study}

After quarantine and acclimation, the rats were divided by stratified randomization into 6 body weight-matched groups of each sex, each comprising 10 rats. The rats were individually housed in cages placed in six wholebody inhalation chambers.

Rats were exposed to airflow containing ETBE vapor at target concentrations of 0 (control), 50, 150, $500,1,500$ or $5,000 \mathrm{ppm}$ for $6 \mathrm{hr} /$ day, 5 days/week for 13 weeks. The highest concentration was determined by reference to Medinsky et al. (1999): increased incidences of bone marrow congestion were observed in female rats exposed to ETBE at concentrations of 1,750 or 5,000 ppm for 13 weeks. Concentrations of ETBE vapor in the inhalation chambers were maintained at constant levels by measuring ETBE concentration using a gas chromatograph (GC-14B, Shimadzu, Kyoto, Japan) at intervals of $15 \mathrm{~min}$ throughout the 13-week exposure period (Senoh et al., 2003). The concentrations of ETBE in the 50, 150, $500,1,500$ and 5,000 ppm-exposed groups were $50 \pm 0.2$, $150 \pm 0.5,501 \pm 2.2,1,505 \pm 6.1$ and 5,005 $\pm 14.3 \mathrm{ppm}$ (Mean \pm S.D.), respectively.

\section{Intraperitoneal injection study}

After quarantine and/or acclimation, the rats were divided by stratified randomization into 6 body weightmatched groups of each sex, each comprising 5 rats. 8-week-old rats were given two consecutive daily intraperitoneal (ip) injections of ETBE in olive oil at doses of 0 (control), 250, 500, 1,000 or $2,000 \mathrm{mg} / \mathrm{kg} / \mathrm{day}$. In addition, as a positive control, 5 rats of each sex were given a single intraperitoneal injection of mitomycin $\mathrm{C}$ (MMC) at a dose of $1 \mathrm{mg} / \mathrm{kg}$. Since ETBE is volatile chemical, ETBE is retained and absorbed more in the body by ip injection compared to oral administration. Intraperitoneal injection was considered suitable for assessing ETBE in vivo genotoxicity. The highest dose of ETBE was determined based on the upper limit dose in the OECD guideline (OECD, 1997), and the dose of MMC was the same as in our historical studies. $24 \mathrm{hr}$ after the final injection, the animals were killed, and smear specimens were prepared from the bone marrows.

\section{Micronucleus assay}

The micronucleus assay was performed on cells collected from the femurs of rats exposed to 0, 1,600, 4,000, and 10,000 ppm ETBE in the drinking-water; rats exposed to $0,500,1,500$, and 5,000 ppm ETBE vapor; rats injected with $0,250,500$, and $1,000 \mathrm{mg} / \mathrm{kg} /$ day ETBE in olive oil (all animals injected with 2,000 mg/kg/day ETBE died after the first injection); and from rats injected with MMC. Bone marrow cells were flushed out of the left femur with fatal calf serum and smeared on glass slides. After drying, the slides were fixed with methanol and stained with acridine-orange (Hayashi et al., 1983). All the slides were randomized and coded and examined at a magnification of x400 using a fluorescent microscope (BX51, Olympus, Tokyo, Japan). For each rat, 2,000 polychromatic erythrocytes (PCE) were scored and the number of PCE containing micronuclei (MNPCE) was recorded. The frequency of PCE to total erythrocytes (PCE and normochromatic erythrocytes) was determined by scoring 1,000 total erythrocytes and recording the number of PCE.

\section{Clinical observations and pathological examinations}

The animals were observed daily for their clinical signs and mortality. Body weight and food and water consumption per group were measured once a week for 13 weeks. All rats received complete necropsy. For hematology and blood biochemistry, blood was collected from the abdominal aorta under etherization at the end of the study period after overnight fasting. The blood samples were analyzed with an automatic blood cell analyzer (ADVIA 120, Bayer Co., Tarrytown, NY, USA) for hematology, and an automatic analyzer (Hitachi 7080, Hitachi, 
Micronucleus induction activity of ethyl tertiary-butyl ether
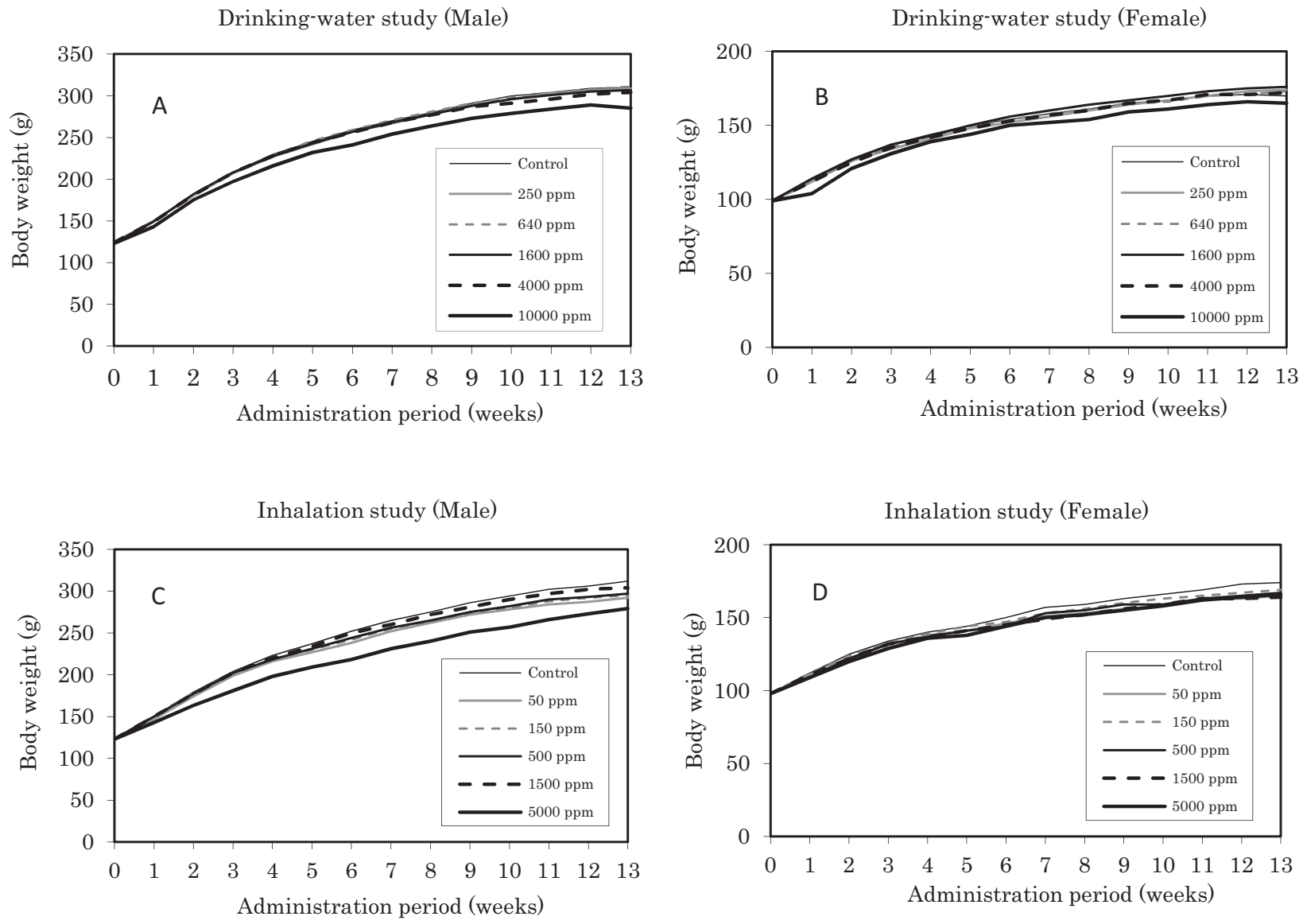

Fig. 1. Growth curves for male (A) and female (B) rats orally administrated ETBE in the drinking-water, and male (C) and female (D) rats exposed to ETBE vapor for 13 weeks.

Ltd., Ibaraki, Japan) for blood biochemistry. Organs were removed, weighed, and examined for macroscopic lesions at necropsy. The tissues were fixed in $10 \%$ neutral buffered formalin, embedded in paraffin, and tissue sections $5 \mu \mathrm{m}$ in thickness were prepared and stained with hematoxylin and eosin ( $\mathrm{H} \& \mathrm{E})$.

\section{Statistical analysis}

Two-sided tests were used for all statistical analyses. Body weight, food consumption, hematological blood, biochemical parameters and organ weight were analyzed by Dunnett's test. Pathological examinations were analyzed by the chi-square test. The frequencies of micronucleated polychromatic erythrocytes (MNPCE) were analyzed by the method of Kastenbaum and Bowman (Kastenbaum and Bowman, 1970). The frequency of PCE to E was analyzed by the Wilcoxon rank-sum test $(\mathrm{P}<0.05)$. Statistical significance at $p<0.05$ and $p<0.01$ are indicated in the tables.

\section{RESULTS}

\section{3-week drinking-water study}

The average daily ETBE-intake throughout the treatment period in the $250,640,1,600,4,000$ and 10,000 ppm groups were 17 (12-27), 40 (30-62), 101 (77-149), 259 (208-354) and 626 (484-804) $\mathrm{mg} / \mathrm{kg} /$ day (values in parenthesis indicate the range of drinking water consumption) for males and 27 (22-33), 58 (46-71), 120 (98-166), 267 (222-393) and 629 (497-835) $\mathrm{mg} / \mathrm{kg} /$ day for females. Neither mortality nor clinical signs were found in any of the groups. There was a slight, but statistically significant, decrease in the body weight of males, but not females, administrated 10,000 ppm ETBE compared with the control throughout the treatment period (Fig. 1). Average body weights at the end of the treatment period in 
rats administered $250,640,1,600,4,000$ and $10,000 \mathrm{ppm}$ ETBE were $100 \%, 100 \%, 99 \%, 98 \%$ and $92 \%$ of the control for males and $102 \%, 102 \%, 104 \%, 101 \%$ and $97 \%$ of the control for females. Food consumption by males administered 10,000 ppm ETBE was suppressed at week 1 and there was a tendency to decrease water consumption dose-dependently in both sexes (data not shown), however, there were no significant differences in food or water consumption during the administration period in either sex.

The micronucleus assay was performed on cells collected from the femurs of the rats administered 0, 1,600, 4,000 , and 10,000 ppm ETBE. The percentages of PCE with micronuclei to total PCE (MNPCE (\%)) and PCE to total erythrocytes (PCE (\%)) in males and females are shown in Table 2. The MNPCE (\%) and PCE (\%) in the controls $(0.16 \pm 0.08 \%$ and $24.2 \pm 3.5 \%$ in males and $0.10 \pm 0.07 \%$ and $23.7 \pm 3.8 \%$ in females) were within the background data of F344 rats in our facility. No significant differences in the MNPCE (\%) or PCE (\%) were observed in any of the treated groups of either sex compared to the control groups.

There was a slight, but significant, decrease in the red blood cell count and hemoglobin concentration in females administered 640, 4,000 and 10,000 ppm ETBE (Table 3). There was also a slight, but significant, decrease in hematocrit in females administered 640 and 10,000 ppm ETBE. No other significant changes in hematological parameters were observed in any of the treatment groups of either sex.

Analysis of blood biochemistry revealed a significant and dose-dependent increase of urea nitrogen in males administered $640 \mathrm{ppm}$ and higher levels of ETBE; there was no significant change in urea nitrogen in females (date not shown). No other significant changes in blood biochemistry were observed in any of the treatment groups of either sex.

Histopathological examination revealed significantly increased incidences of regeneration and granular casts in the proximal tubules in the kidney in males given 1,600 ppm or higher levels of ETBE. There was also a significant enhancement of the degree of hyaline droplet accumulation in the cytoplasm of proximal tubular epithelium of the kidney in males receiving 10,000 ppm ETBE. These renal lesions were not observed in any of the female groups. Significant increases in kidney weights were observed in males given 1,600 ppm or higher levels of ETBE and in females given 640 ppm or higher levels of ETBE (date not shown).

\section{3-week inhalation study}

Neither mortality nor clinical signs were found in any of the groups. There was a slight, but statistically significant, decrease in the body weight of males, but not females, exposed to 5,000 ppm ETBE compared with the control throughout the treatment period (Fig. 1). Average body weights at the end of the treatment in rats exposed to 50,150, 500, 1,500 and 5,000 ppm ETBE were $94 \%, 95 \%, 95 \%, 97 \%$, and $89 \%$ of the control for males and 95\%, 97\%, 96\%, 94\%, and 95\%, of the control for females. Food consumption by males exposed to 5,000 ppm ETBE was suppressed early during the exposure period (data not shown).

The micronucleus assay was performed on cells collected from the femurs of the rats exposed to 0,500, 1,500, and 5,000 ppm ETBE. The MNPCE (\%) and PCE (\%) in males and females is shown in Table 4. The MNPCE (\%) and PCE (\%) in the controls $(0.14 \pm 0.06 \%$ and 23.3 $\pm 2.6 \%$ in males and $0.16 \pm 0.13 \%$ and $24.2 \pm 2.6 \%$ in females) were within the background data of F344 rats in our facility. No significant differences in the MNPCE (\%) or PCE (\%) were observed in any of the treated groups of either sex compared to the control groups.

There was a slight, but significant, decrease in the red blood cell count and hemoglobin concentration in males exposed to 5,000 ppm ETBE (Table 5). No other significant changes in hematological parameters were observed in any of the treatment groups of either sex.

Analysis of blood biochemistry revealed significant changes in total protein, parameters related to lipids, and urea nitrogen in the 5,000 ppm-exposed males (data not shown). No other significant changes in blood biochemistry were observed in any of the treatment groups of either sex.

Histopathological examination revealed significantly increased incidences of regeneration in the proximal tubules in the kidney in the 5,000 ppm-exposed males (data not shown). Significant increases in kidney weights were found in both sexes exposed to 1,500 ppm and above levels of ETBE, and significant increases in liver weights were found in both sexes exposed to 5,000 ppm ETBE.

\section{Intraperitoneal injection study}

All animals given $2,000 \mathrm{mg} / \mathrm{kg} /$ day ETBE died after treatment day 1 . The micronucleus data are shown in Table 6. No significant differences in the MNPCE (\%) and PCE (\%) were observed in any of the treated groups of either sex compared to the control groups. The MNPCE (\%) in the positive control group, the MMC-treated group, was markedly increased in both males $(1.45 \pm 0.33 \%)$ and females $(1.04 \pm 0.10 \%)$ compared to the vehicle control 
Micronucleus induction activity of ethyl tertiary-butyl ether

Table 2. Results of micronucleus induction in the bone marrow of rats orally administrated ETBE in the drinking-water for 13 weeks

\begin{tabular}{lccccc}
\hline Dose & Number of animal & \multicolumn{2}{c}{ PCE/E $(\%)$} & \multicolumn{2}{c}{ MNPCE/PCE (\%) } \\
\hline Male & 10 & $24.2 \pm 3.5^{\mathrm{a}}$ & $\left(18.1^{\mathrm{b}}-29.4^{\mathrm{c}}\right)$ & $0.16 \pm 0.08^{\mathrm{d}}$ & $\left(0.05^{\mathrm{e}}-0.30^{\mathrm{f}}\right)$ \\
$0 \mathrm{ppm}$ & & & & & \\
$1,600 \mathrm{ppm}$ & 10 & $26.3 \pm 5.4$ & $(17.3-35.3)$ & $0.17 \pm 0.12$ & $(0-0.35)$ \\
$4,000 \mathrm{ppm}$ & 10 & $24.7 \pm 4.9$ & $(17.7-32.3)$ & $0.14 \pm 0.06$ & $(0.05-0.25)$ \\
$10,000 \mathrm{ppm}$ & 10 & $23.8 \pm 5.4$ & $(16.5-31.4)$ & $0.19 \pm 0.15$ & $(0-0.45)$ \\
\hline Female & 10 & $23.7 \pm 3.8$ & $(18.1-29.4)$ & $0.10 \pm 0.07$ & $(0.05-0.25)$ \\
$0 \mathrm{ppm}$ & & & & & \\
$1,600 \mathrm{ppm}$ & 10 & $24.7 \pm 3.4$ & $(21.1-30.3)$ & $0.16 \pm 0.09$ & $(0.05-0.30)$ \\
$4,000 \mathrm{ppm}$ & 10 & $24.8 \pm 2.6$ & $(20.5-29.8)$ & $0.09 \pm 0.06$ & $(0-0.20)$ \\
$10,000 \mathrm{ppm}$ & 10 & $23.6 \pm 4.2$ & $(15.1-29.3)$ & $0.13 \pm 0.07$ & $(0.05-0.25)$ \\
\hline
\end{tabular}

a) Average \pm S.D. of PCE/E

b) Minimum value of $\mathrm{PCE} / \mathrm{E}$

c) Maximum value of $\mathrm{PCE} / \mathrm{E}$

d) Average \pm S.D. of MNPCE/PCE

e) Minimum value of MNPCE/PCE

f) Maximum value of MNPCE/PCE

Table 3. Results of hematology in rats orally administrated ETBE in the drinking-water for 13 weeks

\begin{tabular}{lcccccccc} 
Dose & $\begin{array}{c}\text { Number } \\
\text { of animal }\end{array}$ & $\begin{array}{c}\mathrm{RBC} \\
\left(10^{6 / \mu l}\right)\end{array}$ & $\begin{array}{c}\mathrm{Hb} \\
(\mathrm{g} / \mathrm{dl})\end{array}$ & $\begin{array}{c}\text { Hematocrit } \\
(\%)\end{array}$ & $\begin{array}{c}\mathrm{MCV} \\
(\mathrm{fl})\end{array}$ & $\begin{array}{c}\mathrm{MCH} \\
(\mathrm{pg})\end{array}$ & $\begin{array}{c}\text { Platelet counts } \\
\left(10^{3} / \mu \mathrm{l}\right)\end{array}$ & $\begin{array}{c}\text { Reticulocyte } \\
(\%)\end{array}$ \\
\hline Male & 10 & $9.35 \pm 0.15$ & $16.3 \pm 0.3$ & $43.5 \pm 0.8$ & $46.5 \pm 0.4$ & $17.5 \pm 0.3$ & $644 \pm 50$ & $1.9 \pm 0.2$ \\
$0 \mathrm{ppm}$ & & & & & & & & \\
$250 \mathrm{ppm}$ & 10 & $9.30 \pm 0.14$ & $16.4 \pm 0.3$ & $43.6 \pm 0.6$ & $46.9 \pm 0.3$ & $17.6 \pm 0.2$ & $673 \pm 47$ & $2.0 \pm 0.2$ \\
$640 \mathrm{ppm}$ & 10 & $9.29 \pm 0.12$ & $16.3 \pm 0.2$ & $43.3 \pm 0.5$ & $46.6 \pm 0.4$ & $17.6 \pm 0.1$ & $672 \pm 40$ & $1.9 \pm 0.2$ \\
$1,600 \mathrm{ppm}$ & 10 & $9.28 \pm 0.16$ & $16.4 \pm 0.2$ & $43.4 \pm 0.5$ & $46.8 \pm 0.5$ & $17.6 \pm 0.2$ & $677 \pm 67$ & $1.9 \pm 0.2$ \\
$4,000 \mathrm{ppm}$ & 10 & $9.24 \pm 0.19$ & $16.3 \pm 0.2$ & $43.2 \pm 0.8$ & $46.8 \pm 0.5$ & $17.6 \pm 0.3$ & $637 \pm 45$ & $1.8 \pm 0.2$ \\
$10,000 \mathrm{ppm}$ & 10 & $9.28 \pm 0.15$ & $16.4 \pm 0.3$ & $43.3 \pm 0.9$ & $46.7 \pm 1.1$ & $17.6 \pm 0.4$ & $627 \pm 79$ & $1.6 \pm 0.4$ \\
\hline Female & 10 & $8.77 \pm 0.15$ & $16.5 \pm 0.3$ & $42.8 \pm 0.8$ & $48.8 \pm 0.6$ & $18.8 \pm 0.2$ & $721 \pm 59$ & $1.7 \pm 0.2$ \\
$0 \mathrm{ppm}$ & & & & & & & & \\
$250 \mathrm{ppm}$ & 10 & $8.64 \pm 0.14$ & $16.3 \pm 0.3$ & $42.4 \pm 0.6$ & $49.1 \pm 0.4$ & $18.8 \pm 0.1$ & $702 \pm 61$ & $1.8 \pm 0.2$ \\
$640 \mathrm{ppm}$ & 10 & $8.46 \pm 0.28^{* *}$ & $16.0 \pm 0.5^{* *}$ & $41.5 \pm 1.1 * *$ & $49.1 \pm 0.5$ & $18.9 \pm 0.2$ & $725 \pm 31$ & $1.8 \pm 0.3$ \\
$1,600 \mathrm{ppm}$ & 10 & $8.58 \pm 0.15$ & $16.2 \pm 0.2$ & $42.2 \pm 0.8$ & $49.2 \pm 0.4$ & $18.9 \pm 0.2$ & $702 \pm 41$ & $1.8 \pm 0.3$ \\
$4,000 \mathrm{ppm}$ & 10 & $8.54 \pm 0.15^{*}$ & $16.1 \pm 0.2^{*}$ & $42.0 \pm 0.8$ & $49.2 \pm 0.4$ & $18.9 \pm 0.1$ & $698 \pm 34$ & $1.8 \pm 0.2$ \\
$10,000 \mathrm{ppm}$ & 10 & $8.48 \pm 0.24^{* *}$ & $15.9 \pm 0.4 * *$ & $41.5 \pm 1.1 * *$ & $49.0 \pm 0.3$ & $18.8 \pm 0.2$ & $674 \pm 54$ & $1.8 \pm 0.2$ \\
\hline Vas are & & & & & & & &
\end{tabular}

Values are average \pm S.D.

RBC: Red blood cell counts, Hb: Hemoglobin concentration, MCV: Mean corpuscular volume, MCH: Mean corpusclar hemoglobin.

$*$ and $* *$ : Statistical difference from control group at $\mathrm{p}<0.05$ and $\mathrm{p}<0.01$ (Dunnett's test).

group. The MNPCE (\%) and PCE (\%) in the vehicle controls $(0.13 \pm 0.08 \%$ and $26.4 \pm 3.0 \%$ in males and $0.11 \pm$ $0.07 \%$ and $23.4 \pm 5.4 \%$ in females) were within the background data of F344 rats in our facility.

\section{DISCUSSION}

In the present study, administration of ETBE in the drinking water for 13 weeks resulted in significantly decreased red blood cell counts and hemoglobin concentration in female rats administered 640, 4,000 and 10,000 ppm ETBE. Similarly, exposure to ETBE vapor for 
Table 4. Results of micronucleus induction in the bone marrow of rats exposed to ETBE vapor for 13 weeks

\begin{tabular}{lccccc}
\hline Dose & Number of animal & \multicolumn{2}{c}{ PCE/E(\%) } & \multicolumn{2}{c}{ MNPCE/PCE(\%) } \\
\hline Male & 10 & $23.3 \pm 2.6^{\mathrm{a}}$ & $\left(18.4^{\mathrm{b}}-26.9^{\mathrm{c}}\right)$ & $0.14 \pm 0.6^{\mathrm{d}}$ & $\left(0.05^{\mathrm{e}}-0.20^{\mathrm{f}}\right)$ \\
$0 \mathrm{ppm}$ & & & & & \\
$500 \mathrm{ppm}$ & 10 & $24.4 \pm 3.2$ & $(19.4-28.9)$ & $0.16 \pm 0.07$ & $(0.05-0.25)$ \\
$1,500 \mathrm{ppm}$ & 10 & $23.5 \pm 4.3$ & $(17.5-30.2)$ & $0.17 \pm 0.07$ & $(0.05-0.30)$ \\
$5,000 \mathrm{ppm}$ & 10 & $23.5 \pm 5.4$ & $(16.4-33.3)$ & $0.18 \pm 0.10$ & $(0.05-0.40)$ \\
\hline Female & 10 & $24.2 \pm 2.6$ & $(19.1-27.7)$ & $0.16 \pm 0.13$ & $(0.05-0.40)$ \\
$0 \mathrm{ppm}$ & 10 & & & & \\
$500 \mathrm{ppm}$ & 10 & $23.4 \pm 2.4$ & $(19.7-27.1)$ & $0.18 \pm 0.08$ & $(0.10-0.35)$ \\
$1,500 \mathrm{ppm}$ & 10 & $25.1 \pm 5.4$ & $(14.5-34.4)$ & $0.16 \pm 0.09$ & $(0-0.30)$ \\
$5,000 \mathrm{ppm}$ & $25.0 \pm 2.4$ & $(22.4-29.7)$ & $0.16 \pm 0.08$ & $(0-0.25)$ \\
\hline
\end{tabular}

a) Average \pm S.D. of PCE/E

b) Minimum value of $\mathrm{PCE} / \mathrm{E}$

c) Maximum value of PCE/E

d) Average \pm S.D. of MNPCE/PCE

e) Minimum value of MNPCE/PCE

f) Maximum value of MNPCE/PCE

Table 5. Results of hematology in rats exposed to ETBE vapor for 13 weeks

\begin{tabular}{|c|c|c|c|c|c|c|c|c|}
\hline Dose & $\begin{array}{l}\text { Number } \\
\text { of animal }\end{array}$ & $\begin{array}{c}\mathrm{RBC} \\
\left(10^{6} / \mu \mathrm{l}\right)\end{array}$ & $\begin{array}{l}\mathrm{Hb} \\
(\mathrm{g} / \mathrm{dl})\end{array}$ & $\begin{array}{c}\text { Hematocrit } \\
(\%)\end{array}$ & $\begin{array}{l}\text { MCV } \\
\text { (fl) }\end{array}$ & $\begin{array}{c}\mathrm{MCH} \\
(\mathrm{pg})\end{array}$ & $\begin{array}{l}\text { Platelet counts } \\
\qquad\left(10^{3} / \mu \mathrm{l}\right)\end{array}$ & $\begin{array}{c}\text { Reticulocyte } \\
(\%)\end{array}$ \\
\hline Male & 10 & $9.34 \pm 0.22$ & $16.2 \pm 0.4$ & $42.7 \pm 1.0$ & $45.7 \pm 0.4$ & $17.3 \pm 0.1$ & $663 \pm 36$ & $1.8 \pm 0.2$ \\
\hline \multicolumn{9}{|l|}{$0 \mathrm{ppm}$} \\
\hline $50 \mathrm{ppm}$ & 10 & $9.31 \pm 0.19$ & $16.2 \pm 0.3$ & $42.6 \pm 0.9$ & $45.8 \pm 0.5$ & $17.4 \pm 0.2$ & $676 \pm 32$ & $1.7 \pm 0.2$ \\
\hline $150 \mathrm{ppm}$ & 10 & $9.40 \pm 0.24$ & $16.3 \pm 0.4$ & $43.0 \pm 1.1$ & $45.8 \pm 0.4$ & $17.4 \pm 0.3$ & $671 \pm 33$ & $1.5 \pm 0.1$ \\
\hline $500 \mathrm{ppm}$ & 10 & $9.41 \pm 0.32$ & $16.3 \pm 0.3$ & $43.2 \pm 1.3$ & $45.9 \pm 0.5$ & $17.3 \pm 0.4$ & $664 \pm 25$ & $1.6 \pm 0.1$ \\
\hline $1,500 \mathrm{ppm}$ & 10 & $9.31 \pm 0.20$ & $16.1 \pm 0.2$ & $42.7 \pm 0.7$ & $45.9 \pm 0.5$ & $17.3 \pm 0.3$ & $681 \pm 34$ & $1.6 \pm 0.2$ \\
\hline $5,000 \mathrm{ppm}$ & 10 & $9.06 \pm 0.15^{*}$ & $15.8 \pm 0.2^{*}$ & $41.8 \pm 0.5$ & $46.2 \pm 0.5$ & $17.4 \pm 0.3$ & $719 \pm 32$ & $1.6 \pm 0.2$ \\
\hline Female & 10 & $8.76 \pm 0.12$ & $16.3 \pm 0.2$ & $42.3 \pm 0.5$ & $48.4 \pm 0.4$ & $18.6 \pm 0.2$ & $696 \pm 60$ & $1.5 \pm 0.2$ \\
\hline \multicolumn{9}{|l|}{$0 \mathrm{ppm}$} \\
\hline $50 \mathrm{ppm}$ & 10 & $8.74 \pm 0.19$ & $16.3 \pm 0.4$ & $42.3 \pm 0.9$ & $48.4 \pm 0.4$ & $18.7 \pm 0.2$ & $694 \pm 30$ & $1.6 \pm 0.2$ \\
\hline $150 \mathrm{ppm}$ & 10 & $8.72 \pm 0.23$ & $16.3 \pm 0.4$ & $42.2 \pm 1.1$ & $48.4 \pm 0.3$ & $18.6 \pm 0.2$ & $705 \pm 40$ & $1.7 \pm 0.2$ \\
\hline 500 ppm & 10 & $8.67 \pm 0.20$ & $16.2 \pm 0.3$ & $42.1 \pm 0.9$ & $48.6 \pm 0.4$ & $18.7 \pm 0.2$ & $700 \pm 31$ & $1.6 \pm 0.2$ \\
\hline $1,500 \mathrm{ppm}$ & 10 & $8.65 \pm 0.20$ & $16.1 \pm 0.3$ & $41.8 \pm 1.1$ & $48.3 \pm 0.3$ & $18.6 \pm 0.1$ & $703 \pm 42$ & $1.6 \pm 0.2$ \\
\hline $5,000 \mathrm{ppm}$ & 10 & $8.72 \pm 0.21$ & $16.1 \pm 0.3$ & $42.0 \pm 0.8$ & $48.2 \pm 0.4$ & $18.5 \pm 0.2$ & $739 \pm 51$ & $1.6 \pm 0.3$ \\
\hline
\end{tabular}

Values are average \pm S.D.

RBC: Red blood cell counts, Hb: Hemoglobin concentration, MCV: Mean corpuscular volume, MCH: Mean corpusclar hemoglobin.

$*$ and **: Statistical difference from control group at $\mathrm{p}<0.05$ and $\mathrm{p}<0.01$ (Dunnett's test).

13 weeks significantly decreased red blood cell counts and hemoglobin concentration in male rats exposed to 5,000 ppm ETBE. These results indicate that effective levels of ETBE and/or its metabolites were delivered to the bone marrow, and therefore test animals were exposed to levels of ETBE sufficient to evaluate its genotoxicity in bone marrow cells. ETBE did not increase the frequency of micronucleated polychromatic erythrocytes in the bone marrow in any of the ETBE-exposed groups of either sex. 
Micronucleus induction activity of ethyl tertiary-butyl ether

Table 6. Results of micronucleus induction in the bone marrow of rats intraperitoneally injected with ETBE on two consecutive days

\begin{tabular}{|c|c|c|c|c|c|}
\hline \multirow{2}{*}{$\begin{array}{l}\text { Dose } \\
\text { Male }\end{array}$} & \multirow{2}{*}{$\frac{\text { Number of animal }}{5}$} & \multicolumn{2}{|c|}{ PCE/E (\%) } & \multicolumn{2}{|c|}{ MNPCE/PCE (\%) } \\
\hline & & $26.4 \pm 3.0 \mathrm{a}$ & $\left(22.8^{b}-30.6^{c}\right)$ & $0.13 \pm 0.08 \mathrm{~d}$ & $\left(0.05^{\mathrm{e}}-0.20^{\mathrm{f}}\right)$ \\
\hline \multicolumn{6}{|l|}{$0 \mathrm{mg} / \mathrm{kg} /$ day } \\
\hline $250 \mathrm{mg} / \mathrm{kg} /$ day & 5 & $26.5 \pm 4.0$ & $(22.1-32.8)$ & $0.12 \pm 0.06$ & $(0.05-0.20)$ \\
\hline $500 \mathrm{mg} / \mathrm{kg} /$ day & 5 & $27.7 \pm 3.4$ & $(22.7-31.5)$ & $0.12 \pm 0.04$ & $(0.05-0.15)$ \\
\hline $1,000 \mathrm{mg} / \mathrm{kg} /$ day & 5 & $24.5 \pm 5.4$ & $(18.6-33.9)$ & $0.18 \pm 0.04$ & $(0.15-0.25)$ \\
\hline $2,000 \mathrm{mg} / \mathrm{kg} /$ day & $5^{g}$ & & & & \\
\hline MMC $1 \mathrm{mg} / \mathrm{kg}$ & 5 & $24.3 \pm 3.2$ & $(18.8-26.7)$ & $1.45 \pm 0.33 * *$ & $(0.95-1.80)$ \\
\hline Female & 5 & $23.4 \pm 5.4$ & $(14.4-27.1)$ & $0.11 \pm 0.07$ & $(0.05-0.20)$ \\
\hline \multicolumn{6}{|l|}{$0 \mathrm{mg} / \mathrm{kg} /$ day } \\
\hline $250 \mathrm{mg} / \mathrm{kg} /$ day & 5 & $26.2 \pm 4.7$ & $(21.1-32.1)$ & $0.18 \pm 0.06$ & $(0.10-0.25)$ \\
\hline 500 mg/kg/day & 5 & $26.6 \pm 4.2$ & $(21.5-33.2)$ & $0.12 \pm 0.08$ & $(0.05-0.20)$ \\
\hline $1,000 \mathrm{mg} / \mathrm{kg} /$ day & 5 & $29.5 \pm 5.2$ & $(25.3-38.1)$ & $0.12 \pm 0.04$ & $(0.10-0.20)$ \\
\hline $2,000 \mathrm{mg} / \mathrm{kg} /$ day & $5^{g}$ & & & & \\
\hline MMC 1 mg/kg & 5 & $23.6 \pm 6.6$ & $(16.6-34.4)$ & $1.04 \pm 0.10 * *$ & $(0.95-1.15)$ \\
\hline
\end{tabular}

a) Average \pm S.D. of PCE/E

b) Minimum value of $\mathrm{PCE} / \mathrm{E}$

c) Maximum value of PCE/E

d) Average \pm S.D. of MNPCE/PCE

e) Minimum value of MNPCE/PCE

f) Maximum value of MNPCE/PCE

g) All animals given $2,000 \mathrm{mg} / \mathrm{kg} /$ day ETBE died after treatment day 1 .

**: Statistical difference from control group $\mathrm{p}<0.01$ (Kastenbaum and Bowman, 1970).

Administration of 10,000 ppm ETBE in the drinking water resulted in an average daily ETBE-intake of approximately $626 \mathrm{mg} / \mathrm{kg} / \mathrm{day}$ in males and $629 \mathrm{mg} / \mathrm{kg} /$ day in females. Exposure to 5,000 ppm ETBE vapor resulted in an average ETBE-intake of approximately $640 \mathrm{mg} / \mathrm{kg} /$ day, assuming a respiratory level of $254 \mathrm{ml} /$ $\mathrm{min} / \mathrm{kg}$ (Mauderly, 1982) with a respiratory uptake of $32-34 \%$ for ETBE (Nihlen et al., 1998). In addition to these exposure levels, rats were acutely exposed to ETBE levels of $250,500,1,000$, and $2,000 \mathrm{mg} / \mathrm{kg}$ by intraperitoneal injection of ETBE once a day for two consecutive days. Injection of ETBE at doses of 250, 500 and 1,000 $\mathrm{mg} / \mathrm{kg}$ for two consecutive days did not increase the frequency of micronucleated polychromatic erythrocytes in the bone marrow of rats of either sex: injection of 2,000 $\mathrm{mg} / \mathrm{kg}$ resulted in the death of all injected animals after treatment day 1. Therefore, exposure to ETBE at a level of approximately $600 \mathrm{mg} / \mathrm{kg}$ administered in the drinking water for 13 weeks or exposure to ETBE at a level of approximately $600 \mathrm{mg} / \mathrm{kg}$ administered via inhalation for 13 weeks or acute exposure to ETBE at a level of $1,000 \mathrm{mg} / \mathrm{kg}$ administered via intraperitoneal injection for 2 days had no genotoxic activity in the micronucleus assay. Although the positive control group was not set up in the drinking water and inhalation studies for 13 weeks, it is considered that the appropriate evaluation of the micronucleus studies was performed because the positive control group was set to acute ip injection study and the MNPCE (\%) and PCE (\%) in the controls were within the background data of F344 rats in our facility.

The genotoxicity of ETBE has been reviewed by McGregor (2007): ETBE is negative in the Salmonella typhimurium mutation assay, the $\mathrm{CHO}$ cell chromosome aberration assay, and the V79 cell hprt locus assay. ETBE is also negative when assessed by micronucleus induction in the bone marrow of mice treated with a single gavage administration of ETBE at doses up to 5,000 $\mathrm{mg} / \mathrm{kg}$ or mice administered ETBE via inhalation for $6 \mathrm{hr} /$ day for 5-days at concentrations up to 5,000 ppm. Likewise, MTBE, a structural analog of ETBE, is negative in the Salmonella typhimurium mutation assay, the $\mathrm{CHO}$ cell chromosome aberration assay, the V79 cell hprt locus assay, induction of unscheduled DNA synthesis in primary cultured rat hepatocytes, and micronucleus induction in NIH/3T3 cells (McGregor, 2006). MTBE is also negative in inducing sex-linked recessive lethal mutations in Drosophila melanogaster, induction of unscheduled DNA synthesis induction in hepatocytes and micro- 
nucleus induction in bone marrow cells of mice treated with a single gavage administration of MTBE at a dose of $1,750 \mathrm{mg} / \mathrm{kg}$ or mice administered 8,000 ppm MTBE via inhalation for $6 \mathrm{hr}$ /day for 2 days, and chromosomal aberration in the bone marrow cells of rats administered $8,000 \mathrm{ppm}$ MTBE via inhalation for $6 \mathrm{hr} /$ day for 5 days (McGregor, 2006). In contrast, Mackerer et al. (1996) reported that MTBE was genotoxic in mouse lymphoma L5178Y $t k$ assay with a rat liver-induced metabolic activation system. In this system, the results were negative in the presence of formaldehyde dehydrogenase. Therefore, the genotoxic activity was concluded to be from the formaldehyde generated by metabolism of MTBE (Mackerer et al., 1996; McGregor, 2006). There are also a few reports that MTBE was positive in the reverse mutation assay using Salmonella typhimurium TA102 and induction of DNA strand breakage in human HL-60 leukemia cells (Williams-Hill et al., 1999; McGregor, 2006). Although McGregor re-assessed the ETBE and MTBE literature and concluded that these two compounds were not genotoxic, the genotoxicity of ETBE was evaluated with unpublished data and is unknown for details (McGregor, 2006, 2007).

Metabolism of ETBE is similar in rats and humans (Miller et al., 1997; Amberg et al., 2000; McGregor, 2006, 2007). After inhalation or ingestion, ETBE is promptly absorbed into the blood and rapidly distributed throughout the body. ETBE is metabolized to tertiary-butyl alcohol (TBA) and acetaldehyde in the liver and TBA is further oxidized into 2-methyl-1,2-propanol and 2-hydroxyisobuteric acid and these metabolites are excreted into urine (Bernauer et al., 1998; Amberg et al., 1999, 2000). Of these ETBE metabolites, acetaldehyde is a genotoxic in rodents, inducing gene mutation, sister chromatid exchanges, chromosomal aberrations and micronuclei in cultured mammalian cells and sister chromatid exchange in bone marrow cells of mice and hamsters administered acetaldehyde by intraperitoneal injection (IARC, 1999, Obe et al., 1979, Korte et al., 1981); acetaldehyde is classified as a Group 2B carcinogen by IARC (IARC, 1999). Aldehydes are ordinarily detoxified by acetaldehyde dehydrogenase (ALDH) in the liver and converted into acetate (Gemma et al., 2006). The other metabolites - TBA, 2-methl-1,2-propandiol, and 2-hydroxyisobutyric acid - are not genotoxic (McGregor, 2006). Recently, Weng et al. (2011, 2012) found ETBE induced DNA strand breaks in leukocytes of Aldh2 knockout C57BL/6 mice exposed to 500, 1,750 and 5,000 ppm ETBE vapor for 13 weeks, and DNA strand brakes, modified oxidative DNA strand breaks with hOGG1, and 8-hydroxydeoxguanosin in hepatocytes of knockout mice exposed to 5,000 ppm ETBE vapor. Therefore, in the absence of ALDH, exposure to ETBE results in a genotoxic response. These results are especially relevant for people with low levels of ALDH activity.

ETBE is toxic, but the results of the carcinogenicity studies on ETBE are not consistent. Medinsky et al. (1999) exposed F344 rats and CD-1 mice to 0, 500, 1,750 or 5,000 ppm ETBE vapor for $6 \mathrm{hr} /$ day, 5 days/week for 13 weeks. They found treatment-dependent bone marrow congestion, but without changes in the hematopoietic cell population, in female rats exposed to 1,750 and 5,000 ppm ETBE vapor; testicular seminiferous tubules with spermatocyte degeneration in male rats exposed to 1,750 and 5,000 ppm ETBE vapor; male rat specific increases in the incidence of regenerative foci, rates of renal cell proliferation, and $\alpha 2 \mathrm{u}$-globulin containing protein droplets in the kidneys of all treated male rats; and increases in the incidence of centrilobular hepatocyte hypertrophy and rates of hepatocyte cell proliferation in the liver of male and female mice exposed to 5,000 ppm ETBE vapor. Bird et al. (1997) exposed F344 rats and CD-1 mice to inhalation of MTBE, which is chemically related to ETBE, for 24 months (rats) and 18 months (mice) and found that MTBE, like ETBE, targeted the male rat kidney and the mouse liver: They found an increase in the incidence and severity of chronic progressive nephropathy and increased incidence of renal tubular cell tumors in male rats and an increased incidence of hepatocellular adenomas in female mice. Recently, Saito et al. (2013) reported significant increases in the incidence of hepatocellular adenomas in male rats exposed to 5,000 ppm ETBE vapor for 2 years. When administered by gavage ETBE also has carcinogenesis activity. Maltoni et al. (1999) administered ETBE to Sprague-Dawley rats by gavage at doses of 0,250 , or $1,000 \mathrm{mg} / \mathrm{kg} / \mathrm{day}, 4$ days/week for 104 weeks and observed the rats until natural death. They reported that ETBE caused an increase in total malignant tumors, oncological lesions of the mouth epithelium and forestomach, malignant tumors in the uterus, and hemolymphoreticular neoplasias. However, they also noted that only two doses of ETBE were used and a dose-response relationship between the ETBE concentration and tumor formation was not found. In addition, McGregor (2007) pointed out other limitations of the study: survival rates at 96 weeks were relatively poor, there was insufficient histopathological analysis (no information was provided on pre-neoplastic lesions or time of emergence of the tumor types), there was no treatment-related induction of forestomach dysplasias, and there was no evidence that ETBE induced lymphoid neoplasms. Hagiwara et al. (2011) investigated the promoting potential of ETBE on 
Micronucleus induction activity of ethyl tertiary-butyl ether

tumor development in a medium-term multi-organ carcinogenesis bioassay using rats. They administered 5 carcinogens with different target sites to male F344 rats for 4 weeks to initiate multi-organ carcinogenesis. ETBE was then administered by gavage at daily dose levels of 0,300 or $1,000 \mathrm{mg} / \mathrm{kg}$ until experimental week 28 . They found that ETBE had tumor promoting potential for the thyroid, forestomach, colon, liver, kidney and urinary bladder. In contrast with these reports, Suzuki et al. (2012) reported that administration of ETBE in the drinking-water at doses up to 10,000 ppm for 104 weeks did not have any carcinogenic effect in any organ.

It is notable that the results of the carcinogenicity studies on ETBE noted above appear to correlate with detoxification in the liver. The detoxification of MTBE in hepatocytes prepared from F344 rats reaches saturation at high concentration (Casanova and Heck, 1997), thus detoxification of ETBE is also presumed to reach saturation similarly. A far larger bolus of ETBE is delivered to the liver in the animals treated by gavage compared to animals administered ETBE in the drinking water. Consequently, it is likely that less ETBE is detoxified in gavage treated animals than in drinking water treated animals, and ETBE administered by gavage appears to have carcinogenesis activity (Maltoni et al., 1999; Hagiwara et al., 2011; Suzuki et al., 2012). In inhalation exposed animals, ETBE enters the systemic circulation and is not delivered to the liver and is not detoxified, and ETBE administered via inhalation is carcinogenic (Saito et al., 2013).

In conclusion, the results of present study indicate that ETBE administered in the drinking water or via inhalation caused changes relevant to anemia such as a decrease in red blood cell count and hemoglobin concentration, however, ETBE did not increase the frequency of micronucleated polychromatic erythrocytes in the bone marrow of exposed rats. Intraperitoneal injection of sub-lethal doses of ETBE also did not increase the frequencies of micronucleated polychromatic erythrocytes in the bone marrow of injected rats. Our results are in agreement with the negative results of in vitro mutation tests. Consequently, our results indicate that ETBE has no genotoxic effects on somatic cells in vivo. Therefore, the tumorigenic activities of ETBE administered via inhalation are suggested due to non-genotoxic mechanisms.

\section{ACKNOWLEDGMENTS}

The present studies were contracted with and financially supported by the Japan Petroleum Energy Center and Petroleum Association of Japan.

\section{REFERENCES}

Ahmed, F.E. (2001): Toxicology and human health effects following exposure to oxygenated or reformulated gasoline. Toxicol. Lett., 123, 89-113.

Amberg, A., Rosner, E. and Dekant, W. (1999): Biotransformation and kinetics of excretion of methyl-tert-butyl ether in rats and humans. Toxicol. Sci., 51, 1-8.

Amberg, A., Rosner, E. and Dekant, W. (2000): Biotransformation and kinetics of excretion of ethyl tert-butyl ether in rats and humans. Toxicol. Sci., 53, 194-201.

Bernauer, U., Amberg, A., Scheutzow, D. and Dekant, W. (1998): Biotransformation of 12C- and 2-13C-labeled methyl tert-butyl ether, ethyl tert-butyl ether and tert-butyl alcohol in rats: identification of metabolites in urine by $13 \mathrm{C}$ nuclear magnetic resonance and gas chromatography/mass spectrometry. Chem. Res. Toxicol., 11, 651-658.

Bird, M.G., Burleigh-Flayer, H.D., Chun, J.S., Douglas, J.F., Kneiss, J.J. and Andrews, L.S. (1997): Oncogenicity studies of inhaled methyl tertiary-butyl ether (MTBE) in CD-1 mice and F-344 rats. J. Appl. Toxicol., 17 Suppl. 1, S45-S55.

Casanova, M., and Heck, H.A. (1997): Lack of evidence for the involvement of formaldehyde in the hepatocarcinogenicity of methyl tertiary butyl ether in CD-1 mice. Chem. Biol. Interact., 105, 131-143.

Gemma, S., Vichi, S. and Testai, E. (2006): Individual susceptibility and alcohol effects: biochemical and genetic aspects. Ann. Ist. Super. Sanita., 42, 8-16.

Hagiwara, A., Doi, Y., Imai, N., Nakashima, H., Ono, T., Kawabe, M., Furukawa, F., Tamano, S., Nagano, K. and Fukushima, S. (2011): Medium-term multi-organ carcinogenesis bioassay of ethyl tertiary-butyl ether in rats. Toxicology, 289, 160-166.

Hayashi, M., Sofuni, T. and Ishidate, M.Jr. (1983): An application of Acridine Orange fluorescent staining to the micronucleus test. Mutat. Res., 120, 241-247.

IARC (1999): Re-evaluation of Some Organic Chemicals, Hydrazine and Hydrogen Peroxide. IARC Monographs on the Evaluation of Carcinogenic Risks to Humans. Vol.71. Lyon, France: International Agency for Research on Cancer. pp.319-335.

Kano, H., Goto, K., Suzuki, M., Yamazaki, K., Nishizawa, T., Arito, H., Yamamoto, S. and Matsushima, T. (2002): An exposure system for combined administration of an organic solvent to rodents by inhalation and water-drinking and its operational performance. J. Occup. Health, 44, 119-124.

Kado, N.Y., Kuzmicky, P.A., Loarca-Pina, G. and Mumtaz, M.M. (1998): Genotoxicity testing of methyl tertiary-butyl ether (MTBE) in the Salmonella microsuspension assay and mouse bone marrow micronucleus test. Mutat. Res., 412,131-138.

Kastenbaum, M.A. and Bowman, K.O. (1970): Tables for determining the statistical significance of mutation frequencies. Mutat. Res., 9, 527-549.

Korte, A., Obe, G., Ingwersen, I. and Rückert G. (1981): Influence of chronic ethanol uptake and acute acetaldehyde treatment on the chromosomes of bone-marrow cells and peripheral lymphocytes of Chinese hamsters. Mutat. Res., 88, 389-395.

Lee, L.C., Quintana, P.J.E. and De Peyster, A. (1998): Comet assay evaluation of the effect of methyl-t-butyl ether (MTBE) on rat lymphocytes. Toxicol. Sci., 42 Suppl., 178.

Mackerer, C.R., Angelosanto, F.A., Blackburn, G.R. and Schreiner, A.A. (1996): Identification of formaldehyde as the metabolite responsible for the mutagenicity of methyl tertiary-butyl ether 
T. Noguchi et al.

in the activated mouse lymphoma assay. Proc. Sci. Exp. Biol. Med., 212, 338-341.

Maltoni, C., Belpoggi, F., Soffritti, M. and Minardi, F. (1999): Comprehensive long-term experimental project of carcinogenicity bioassays on gasoline oxygenated additives: plan and first report of results from the study on ethyl-tertiary-butyl ether (ETBE). Eur. J. Oncol., 4, 493-508.

Mauderly, J.L. (1982): The effect of age on respiratory function of fischer-344 rats. Exp. Aging Res., 8, 31-36.

McGregor, D.B., Cruzan, G., Callander, R.D., May, K. and Banton, M. (2005): The mutagenicity testing of tertiary-butyl alcohol, tertiary-butyl acetate and methyl tertiary-butyl ether in Salmonella typhimurium. Mutat. Res., 565, 181-189.

McGregor, D. (2006). Methyl tertiary-butyl ether: studies for potential human health hazards. Crit. Rev. Toxicol., 36, 319-358.

McGregor, D. (2007). Ethyl tertiary-butyl ether: a toxicological review. Crit. Rev. Toxicol., 37, 287-312.

McKee, R.H., Vergnes, J.S., Galvin, J.B., Douglas, J.F., Kneiss, J.J. and Andrews, L.S. (1997): Assessment of the in vivo mutagenic potential of methyl tertiary-butyl ether. J. Appl. Toxicol., 17, S31-S36.

Medinsky, M.A., Wolf, D.C, Cattley, R.C., Wong, B., Janszen, D.B., Farris, G.M., Wright, G.A. and Bond, J.A. (1999): Effects of a thirteen-week inhalation exposure to ethyl tertiary butyl ether on Fischer-344 rats and CD-1 mice. Toxicol. Sci., 51, 108-118.

Miller, M.J., Ferdinandi, E.S., Klan, M., Andrews, L.S., Douglas, J.F. and Kneiss, J.J. (1997): Pharmacokinetics and disposition of methyl t-butyl ether in fisher-344 rats. J. Appl. Toxicol., 17, S3-S12.

National Research Council (NRC) (1996): Guide for the care and use of laboratory animals. National Academies Press. Washington, DC.

Nihlen, A., Lof, A. and Johanson, G. (1998): Controlled ethyl tertbutyl ether (ETBE) exposure of male volunteers. I. Toxicokinetics. Toxicol. Sci., 46, 1-10.

Obe, G., Natarajan, A.T., Meyers, M. and Hertog, A. (1979): Induction of chromosomal aberrations in peripheral lymphocytes of human blood in vitro, and of SCEs in bone-marrow cells of mice in vivo by ethanol and its metabolite acetaldehyde. Mutat. Res., 68, 294-294.

OECD (1998): OECD guideline for testing of chemicals 408 . Repeated Dose 90-Day Oral Toxicity Study. Adopted 21 September, 1998. Organization for Economic Co-operation and Development, Paris.

OECD (1981): OECD guideline for testing of chemicals 413 . Subchronic Inhalation Toxicity: 90-Day Study. Adopted 12 May,
1981. Organization for Economic Co-operation and Development, Paris.

OECD (1997): OECD guideline for testing of chemicals 474. Mammalian Erythrocytes Micronucleus test. Adopted 21 July, 1997. Organization for Economic Co-operation and Development, Paris.

OECD (1998): OECD principles on good laboratory practice. OECD series on principles of good laboratory practice and compliance monitoring No.1. ENV/MC/CHEM (98) 17. 1998. Organization for Economic Co-operation and Development, Paris.

Saito, A., Sasaki, T., Kasai, T., Katagiri, T., Nishizawa, T., Noguchi, T., Aiso, S., Nagano, K. and Fukushima, S. (2013): Hepatotumorigenicity of ethyl tertiary-butyl ether with 2-year inhalation exposure in F344 rats. Arch. Toxicol., 87, 905-914.

Senoh, H., Katagiri, T., Arito, H., Nishizawa, T., Nagano, K., Yamamoto, S. and Mastushima, T. (2003): Toxicity due to 2- and 13-wk inhalation exposures of rats and mice to N,N-dimethylformamide. J. Occup. Health, 45, 365-375.

Suzuki, M., Yamasaki, K., Kano, H., Aiso, S., Nagano, K. and Fukusima, S. (2012): No carcinogenicity of ethyl tertiary-butyl ether by 2 -year oral administration in rats. J. Toxicol. Sci., 37, $1239-1246$

Tokyo Chemical Industry Co., Ltd. (2012): Safety data sheet; tertButyl Ethyl Ether. [http://www.tcichemicals.com/eshop/ja/jp/catalog/msds/B1542.pdf accessed 2013/7/25 ]

Weng, Z., Suda, M., Ohtani, K., Mei, N., Kawamoto, T., Nakajima, T. and Wang, R.S. (2011): Aldh2 knockout mice were more sensitive to DNA damage in leukocytes due to ethyl tertiary butyl ether exposure. Ind. Health, 49, 396-399.

Weng, Z., Suda, M., Ohtani, K., Mei, N., Kawamoto, T., Nakajima, T. and Wang, R.S. (2012): Differential genotoxic effects of subchronic exposure to ethyl tertiary butyl ether in the livers of Aldh2 knockout and wild-type mice. Arch. Toxicol., 86, 675682.

Williams-Hill, D., Spears, C.P., Prakash, S., Olah, G.A., Shamma, T., Mori, T., Kim, L.Y. and Hill, C.K. (1999): Mutagenicity studies of methyl-tert-butylether using the Ames tester strain TA102. Mutat. Res., 446, 15-21.

Zeiger, E., Anderson, B., Haworth, S., Lawlor, T. and Mortelmans, K. (1992): Salmonella mutation tests: V. Results from the testing of 311 chemicals. Environ. Mol. Mutagenesis, 19 Suppl. 21, 2-141.

Zhou, W., Yuan, D., Huang, G., Zhang, H. and Ye, S. (2000): Mutagenicity of methyl tertiary butyl ether. J. Environ. Pathol. Toxicol. Oncol., 16, 35-39. 